\title{
Chromosome 22q in pancreatic endocrine tumors: identification of a homozygous deletion and potential prognostic associations of allelic deletions
}

\author{
Anja Wild, Peter Langer, Ilhan Celik ${ }^{1}$, Brunhilde Chaloupka and Detlef K Bartsch \\ Department of General Surgery and ${ }^{1}$ Institute of Theoretical Surgery, Philipps-University of Marburg, Baldingerstrasse, 35043 Marburg/Lahn, Germany \\ (Correspondence should be addressed to D K Bartsch; Email: bartsch@mailer.uni-marburg.de)
}

\begin{abstract}
Objective: A variety of human tumors frequently show allelic deletions of chromosome 22q, suggesting that inactivation of one or more tumor suppressor genes in this region is important for their tumorigenesis.

Methods: In this study, 23 patients with pancreatic endocrine tumors (PETs), including gastrinomas, VIPomas and non-functioning islet cell carcinomas, were analyzed for loss of heterozygosity (LOH) on chromosome 22q with 12 microsatellite and 7 sequence tagged site markers.

Results: LOH on chromosome 22q was identified in 22 of 23 (96\%) PETs. Markers in the chromosomal region 22q12.1 revealed $\mathrm{LOH}$ rates up to $85 \%$. Notably, one tumor revealed a homozygous deletion in a second region at $22 \mathrm{q} 12.3$. $\mathrm{LOH}$ at this locus occurred more frequently in tumors with distant metastases (10 of 11) compared with tumors without distant metastases ( 3 of $12 ; P=0.0057)$ and, overall, allelic loss of $22 \mathrm{q}$ is positively correlated with distant metastases $(r=0.78 ; P<0.0001)$. Conclusions: These findings are suggestive for novel tumor suppressor gene loci at chromosome $22 \mathrm{q}$ that might contribute to the pathogenesis of PETs, especially to the development of distant metastases.
\end{abstract}

European Journal of Endocrinology 147 507-513

\section{Introduction}

Pancreatic endocrine tumors (PETs) take their direction of differentiation from the pancreatic islet cells and are identified in as many as $1.5 \%$ of unselected autopsy cases (1). Functioning PETs, such as gastrinomas, insulinomas and vasoactive intestinal polypeptide producing tumors (VIPomas), are characterized by the extensive production of single polypeptide hormones that lead to specific clinical syndromes. While some PETs occur in well-described familial syndromes, such as multiple endocrine neoplasia type 1 (MEN1) and von Hippel-Lindau (VHL) syndromes, the vast proportion occur sporadically. Although the histological characteristics of these tumors are very similar, their malignant potential varies greatly. Non-functioning PETs, for example, are malignant in up to $92 \%$ of cases compared with $50-60 \%$ of gastrinomas and $10 \%$ of insulinomas $(1,2)$. Usually PETs have a more indolent behavior than do their highly malignant exocrine counterparts, but they can present with widely metastatic disease. In the absence of local invasiveness or distant metastases, there are no indisputable clinical or histopathological methods to classify PETs as malignant. Consequently, lack of cellular atypia, lymph node or blood vessel invasion are not evidence of a benign phenotype (3). Thus, prognosis cannot reliably be determined when only a primary endocrine pancreatic lesion is present $(1,4)$. In certain tumor types, molecular genetic markers have demonstrated the ability to determine malignancy and prognosis in addition to conventional histology. One key example is chromosome 1p loss in neuroblastomas (5). Our understanding of the molecular pathogenesis of PETs, however, is still limited. Loss of heterozygosity $(\mathrm{LOH})$ on chromosome arm 3p has been found in both familial and non-familial PETs with a suggested relation to malignancy $(4,6)$. Mutations of the DPC4/Smad4 tumor suppressor gene might indicate PETs with a more aggressive phenotype reflected by an early occurrence of metastases (7). It has also been suggested that deletion of chromosome 1 (8) and 11q13 (4) predicts prognosis in PETs. We performed a fine deletion mapping of chromosome $22 \mathrm{q}$ in human PETs and identified potential novel tumor suppressor loci that seem to correlate directly with prognosis.

\section{Materials and methods}

\section{Patients and tissue samples}

Twenty-three fresh-frozen PETs, including twelve nonfunctioning neuroendocrine pancreatic carcinomas 
(NNPC), eight gastrinomas, two VIPomas and one renin-producing PET, were obtained from the tumor bank of the Department of Surgery, Philipps-University of Marburg. The diagnosis of Zollinger-Ellison syndrome was established by clinical symptoms, an elevated fasting serum gastrin level $(>125 \mathrm{pg} / \mathrm{ml})$ in the presence of acid in the stomach, a positive secretin stimulation test defined as increase to a serum gastrin concentration of $>200 \mathrm{pg} / \mathrm{ml}$, and positive immunohistochemistry for gastrin in the tumor. The diagnosis of VIPoma was confirmed by secretory diarrhea $(>6$ liters/day) and a fasting vasoactive intestinal polypeptide VIP concentration $>130 \mathrm{pg} / \mathrm{ml}$. Characteristics of the renin-producing PET have been described previously (9). Tumors were considered as non-functioning if clinically no symptoms of hormonal excess were present and plasma hormone levels were within normal limits. Malignancy was determined based on the strict criteria of infiltrating growth, lymph node or distant metastases. Twenty-one tumors were malignant and two gastrinomas appeared to be benign (Table 1). Clinical follow-up was obtained through the patient's personal physician or at outpatient attendance. Survival was calculated from the time of surgical resection to either death or most recent contact. Informed consent was obtained from all patients. All investigations and all patients' material in this study were assessed under a research protocol approved by the Philipps-University of Marburg Ethic Committee. The tumor samples used for DNA isolation had a neoplastic cellularity between $85 \%$ and $100 \%$ after cryostat microdissection, whereas constitutional normal DNA was derived from blood lymphocytes. Genomic DNA from fresh-frozen tissue and whole blood samples was isolated using the QIAamp DNA kit (Qiagen, Hilden, Germany) according to the manufacturer's protocol.

\section{LOH analysis}

Eleven highly polymorphic microsatellite markers D22S345, D22S1174, D22S351, D22S1167, D22S1144, D22S929, D22S280, D22S283, D22S423, D22S1140, D22S1169, and one expressed sequence tag (EST) marker A006E25 have been chosen for deletion mapping. Their location as shown in Fig. 1 and genomic sequences were confirmed by the published National Center for Biotechnology Information or Sanger Centre chromosome 22q sequences. PCR amplification was performed with fluorescencelabeled oligonucleotides on a MWG Primus 25 PCR cycler (MWG Biotech, Ebersberg, Germany) with a standard protocol. PCR product analysis was performed on a 310 Genetic Analyzer (ABI Applied Biosystems, Foster City, CA, USA) as described by the manufacturer. $\mathrm{LOH}$ was defined as a reduction in intensity of $50 \%$ or

Table 1 Clinical and tumor characteristics of patients with PETs analyzed by 22q allelotyping.

\begin{tabular}{|c|c|c|c|c|c|c|c|}
\hline Patient & $\begin{array}{c}\text { Age at surgery } \\
\text { (years) }\end{array}$ & Tumor type & $\begin{array}{c}\text { Signs of } \\
\text { malignancy } \dagger\end{array}$ & $\begin{array}{l}\text { Primary tumor } \\
\text { size }(\mathrm{mm})\end{array}$ & $\begin{array}{l}\text { Follow-up } \\
\text { (months) }\end{array}$ & $\begin{array}{l}\text { LOH/informative } \\
\text { markers on } 22 q\end{array}$ & $\begin{array}{l}\text { LOH on } \\
22 q 12.3 \ddagger\end{array}$ \\
\hline $20 / 96$ & 50 & Vipoma & Liver metastases & $20 \times 20$ & 71; AWD & $6 / 9$ & No \\
\hline $53 / 96$ & 61 & Non-functioning & IG & $35 \times 35$ & 66; NED & $1 / 11$ & No \\
\hline $74 / 96$ & 56 & Gastrinoma & Liver metastases & $25 \times 25$ & $2 ; \mathrm{DOD}$ & $10 / 11$ & Yes \\
\hline $91 \mathrm{a}$ & 64 & Non-functioning & LN metastases & $35 \times 35$ & $54 ;$ NED & $5 / 9$ & No \\
\hline $106 a$ & 45 & Non-functioning & LN metastases & $70 \times 80 \times 50$ & 73; AWD & $1 / 11$ & No \\
\hline $108 a$ & 62 & Non-functioning & Liver metastases & $30 \times 16$ & $21 ; \mathrm{DOD}$ & $7 / 9$ & Yes \\
\hline $122 a$ & 44 & Reninoma & Liver metastases & $100 \times 50 \times 30$ & 12; DOD & $9 / 10$ & Yes \\
\hline $141 / 98$ & 28 & Gastrinoma & LN metastases & $20 \times 20$ & 59; NED & $1 / 11$ & No \\
\hline $155 / 98$ & 63 & Non-functioning & LN metastases & $100 \times 100$ & 42; NED & $8 / 12$ & Yes \\
\hline $160 a$ & 64 & Non-functioning & LN metastases & $100 \times 65 \times 60$ & 29; NED & $6 / 11$ & Yes \\
\hline $162 / 98$ & 49 & Non-functioning & Liver metastases & $200 \times 200$ & 106; AWD & $7 / 11$ & Yes \\
\hline $164 / 98$ & 58 & Gastrinoma & LN metastases & $5 \times 6$ & 97; NED & $7 / 12$ & No \\
\hline $166 / 98$ & 43 & Non-functioning & Liver metastases & $26 \times 26$ & 192; AWD & $10 / 11$ & Yes \\
\hline $167 / 98$ & 50 & Gastrinoma & None & $20 \times 20$ & 127; NED & $7 / 12$ & No \\
\hline $171 / 98$ & 53 & Non-functioning & LN metastases & $40 \times 40 \times 25$ & 84; NED & $6 / 11$ & Yes \\
\hline $172 / 98$ & 50 & Non-functioning & Liver metastases & $31 \times 31$ & 76; DOD & $7 / 10$ & Yes \\
\hline $177 / 98$ & 57 & Gastrinoma & None & $9 \times 30 \times 5$ & 99; NED & $0 / 10$ & No \\
\hline $179 / 98$ & 53 & Non-functioning & Liver metastases & $40 \times 40$ & 138; AWD & $11 / 11$ & Yes \\
\hline $183 / 98$ & 43 & Gastrinoma & Liver metastases & $8 \times 8$ & 48; AWD & $8 / 9$ & Yes \\
\hline F2III8* & 40 & Gastrinoma & LN metastases & $7 \times 7$ & 127; NED & $1 / 9$ & No \\
\hline F5II1* & 31 & Vipoma & Liver metastases & $350 \times 350$ & 155; AWD & $6 / 11$ & Yes \\
\hline F7III $4^{*}$ & 34 & Non-functioning & Lung metastases & $20 \times 15$ & $114 ;$ NED & $10 / 11$ & Yes \\
\hline F8IV23* & 32 & Gastrinoma & LN metastases & $20 \times 20$ & 80; AWD & $4 / 10$ & No \\
\hline
\end{tabular}

LN, lymph node; IG, infiltrating overgrowth; NED, no evidence of disease, partially after up to three re-operations; AWD, alive with disease; DOD, dead of disease.

* Familial, MEN1-associated.

†At diagnosis or during follow-up.

‡Determined by markers D22S280 and D22S283. 


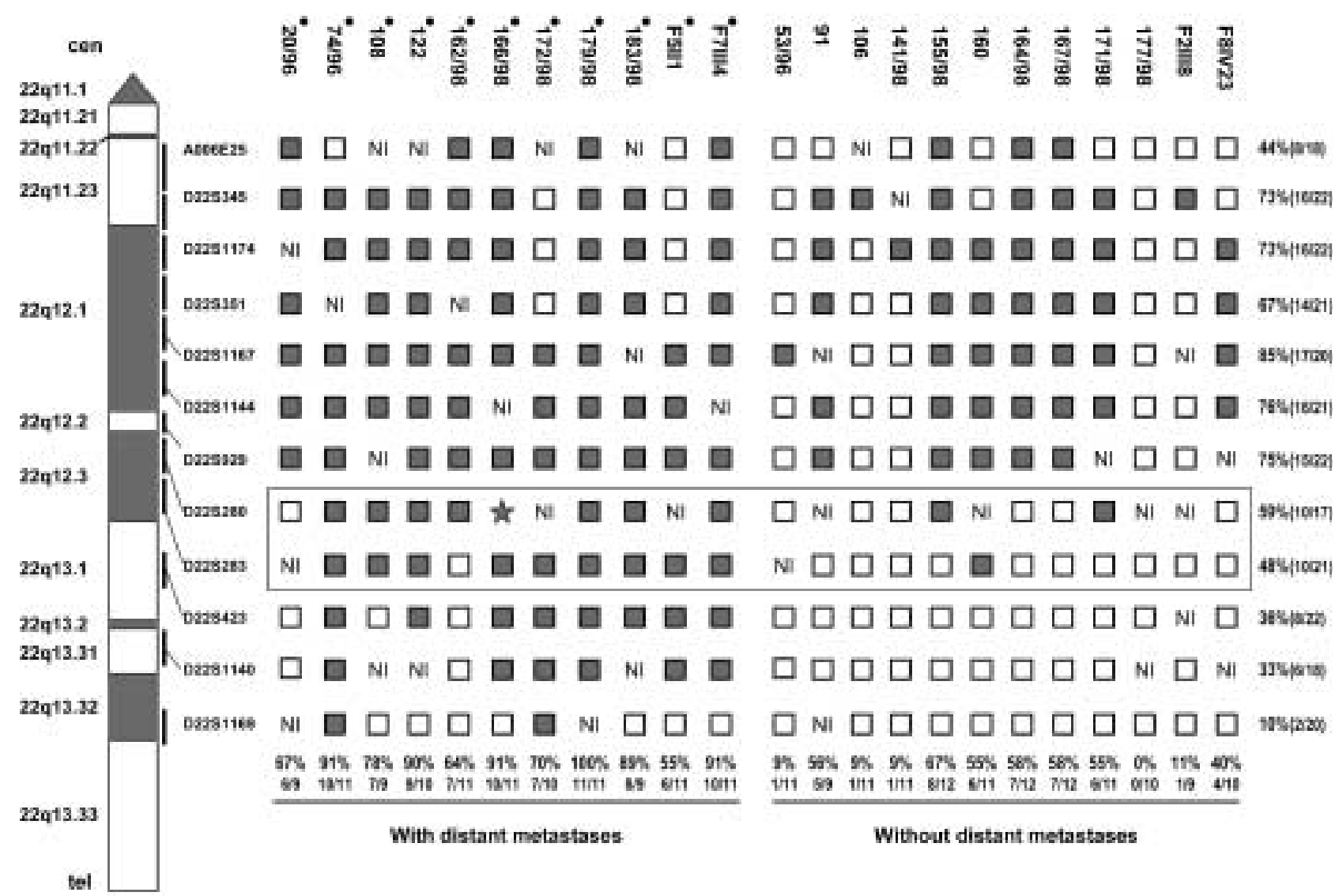

Figure 1 Deletion map of chromosome 22q in PETs. Homozygous deletion (shaded star); retention of heterozygosity (open squares); $\mathrm{LOH}$ (shaded squares); tumors with distant metastases (solid circles). NI, not informative; cen, centomere; tel, telomere. $\mathrm{LOH}$ rates are given in percentage of informative markers. The boxed area indicates the markers D22S280 and D22S283 on 22q12.3 where LOH is significantly correlated with the presence of distant metastases $(r=0.78 ; P<0.0001)$.

more in either of the two alleles as compared with those in constitutional normal DNA, considering the calculated difference between the relative intensity in tumor and corresponding alleles by semiquantitative analysis on a 310 Genetic Analyzer (Fig. 2). Data were analyzed using Genescan version 2.1.1 software (ABI Applied Biosystems).

\section{Qualitative fine deletion mapping}

Since one NNPC (166/98) showed a reproducible homozygous deletion on chromosomal band 22q12.3 corresponding to marker D22S280, we undertook a finer deletion mapping with seven sequence tagged site markers from contiguous clones Z75744 (G05050), Z72521 (G03684), Z72520 (Z72520STS1) and Z73495 (G60706) centromeric of D22S280, and telomeric contig clones Z73979 (G49417), Z98256 (G49339) and AL031592 (G60943). Deletion mapping was performed in all tumors that showed LOH at this locus and all tumors without LOH after standard PCR protocols. PCR products were visualized by ethidium-bromide staining after electrophoresis on $6 \%$ polyacrylamide mini gels. Homozygous deletion was determined as absence of a marker specific signal, verified by primer site mutation analysis (Fig. 3).

\section{Statistics}

Descriptive statistics are expressed as the mean and S.D. value system. The $\mathrm{chi}^{2}$-test with Yates' correction was performed for nominal data. Because of unknown distribution, non-parametric correlation between distant metastases and rate of $\mathrm{LOH}$ was analyzed using the Spearman rank correlation. Survival analysis was performed using the Kaplan-Meier method with the log rank test. $P$ values $<0.05$ were considered as statistically significant. Data were analyzed using SPSS software (version 10).

\section{Results}

We determined the frequency of LOH in 23 primary PETs for $\mathrm{LOH}$ at 12 loci on chromosome 22q. Tumor 
D22S1167

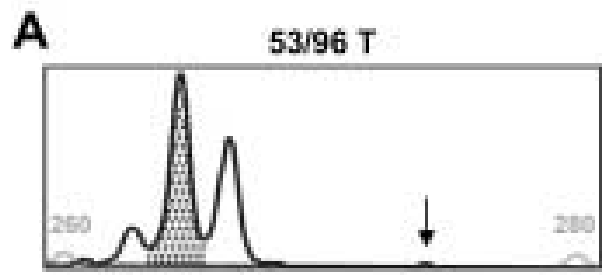

$53 / 96 \mathrm{~N}$

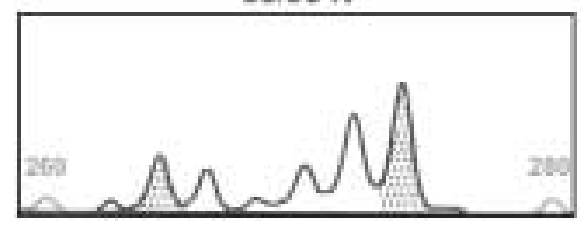

\section{D22S280}

B

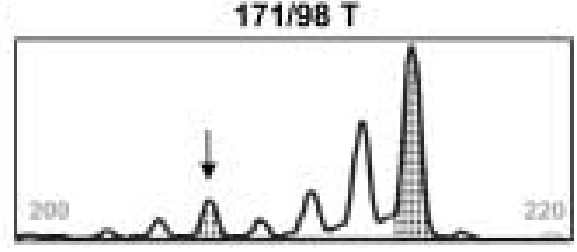

$171 / 98 \mathrm{~N}$

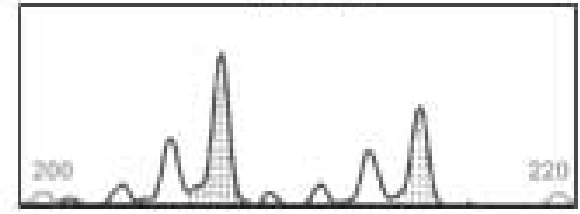

Figure 2 Examples of LOH on chromosome (A) 22q12.1 in NNPC 53/96 with marker D22S1167 and (B) on 22q12.3 in NNPC 171/98 with marker D22S280. Arrows indicate allelic loss. T, tumor DNA; N, 'normal' constitutional DNA; numbers indicate internal DNA length standard given in bp.

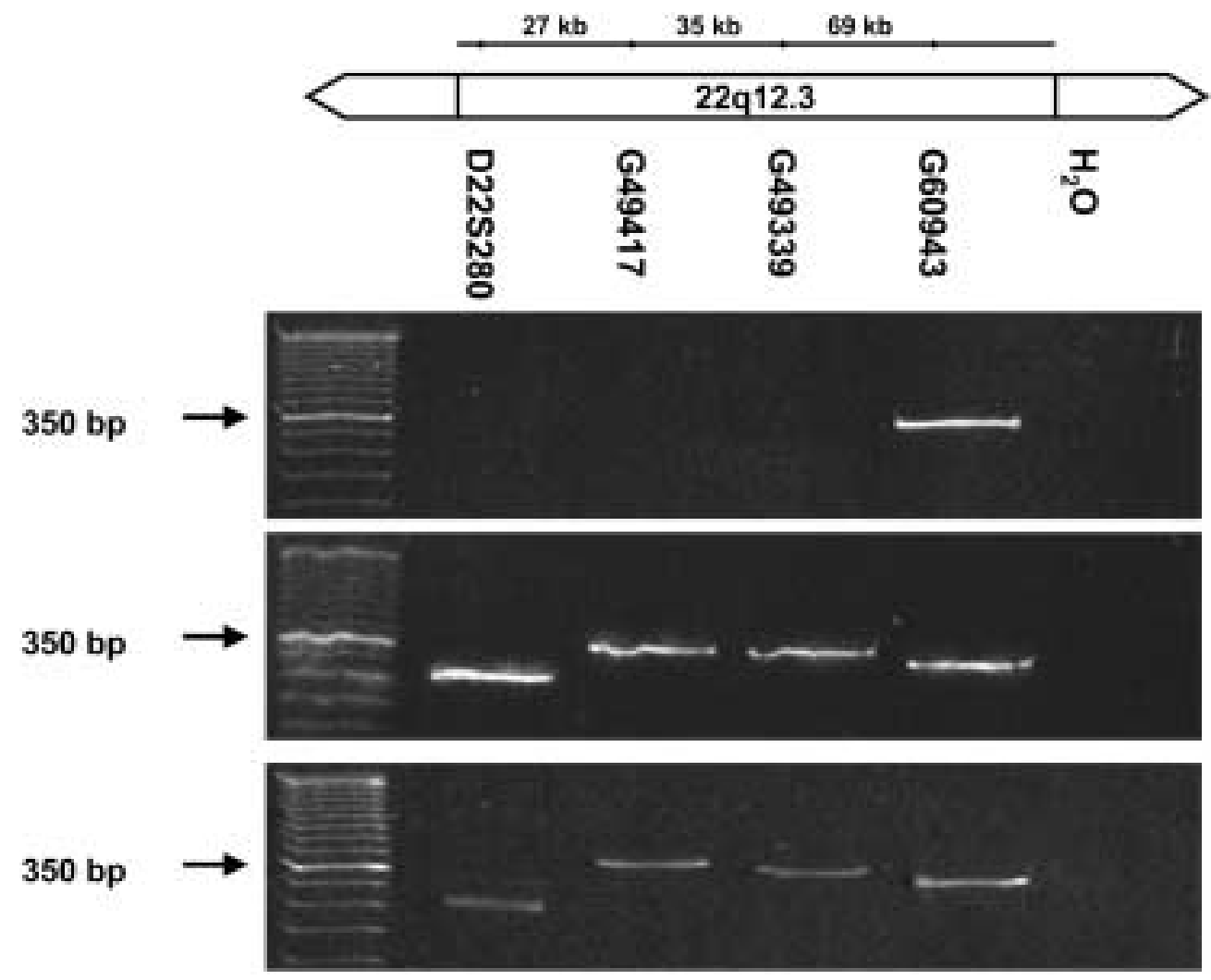

$166 / 98 \mathrm{~T}$

$166 / 98 \mathrm{~N}$

WT

Figure 3 Qualitative fine deletion mapping with markers D22S280, G49417, G49339 and G60943. The tumor DNA of NNPC 166/98 revealed a homozygous deletion in markers D22S280, G49417 and G49339 as shown by the absence of a marker specific signal. T, tumor DNA; N, corresponding 'normal' constitutional DNA; WT, control DNA from wild-type peripheral blood lymphocytes; $\mathrm{H}_{2} \mathrm{O}$ indicates negative control; DNA length standard, $50 \mathrm{bp}$ ladder. Distances between markers are given in kb. 
phenotypes included twelve NNPCs, eight gastrinomas, two VIPomas and one renin-producing PET. Nineteen cases were sporadic and four patients had MEN1 (Table 1). There were 12 males and 11 females with a mean age of 49 (range 28-64) years at the time of surgery. The tumor size ranged from $5 \mathrm{~mm}$ to $350 \mathrm{~mm}$ in diameter (Table 1). All patients were explored, staged and underwent resection of the tumor and/or detectable metastases. At the time of surgery, six patients had localized disease, defined by the absence of any extra-pancreatic spread of the tumor. Nine patients had tumors with lymph node metastases. Three patients presented with synchronous liver metastases and one patient with a synchronous single lung metastasis. During mean follow-up of 81 (range 2192) months seven patients developed liver metastases. At the conclusion of the study, eleven patients had no evidence of disease, eight patients were alive with disease and four patients were deceased due to diffuse liver metastases.

The 19 markers used in this study are localized on chromosomal bands 22q11.22 to 22q13.32 and are distributed over a genomic region of about $25 \mathrm{Mb}$ according to the published sequence data of chromosome $22 \mathrm{q}$ (10). LOH was identified in 22 of $23(96 \%)$ PETs (Fig. 1). All 11 tumors with distant metastases revealed $\mathrm{LOH}$ in more than $60 \%$ of the markers (Fig. 1). Highest $\mathrm{LOH}$ rates were detected on $22 \mathrm{q} 12.1$ at markers D22S1167 and D22S1144 with 85\% $(17 / 20)$ and $76 \%(16 / 21)$ of informative tumors respectively (Fig. 2). In our material, the deletions were large in all but three cases, contributing to different markers on chromosomal bands 22q11.23 and 22q12.1 (Fig. 2). Therefore a smallest common region of overlap for $\mathrm{LOH}$ is hard to define. Notably, NNPC 166/98 showed a homozygous deletion on chromosomal band 22q12.3 corresponding to marker D22S280 that revealed an LOH rate of 59\% (Figs. 1 and 3). After exclusion of a primer site mutation, a fine deletion mapping with seven STS markers spanning approximately $300 \mathrm{~kb}$ around D22S280 was performed in all tumors at this locus. None of the other tumors revealed any homozygous deletion, whereas the homozygous deletion of tumor 166/98 spanned about $70 \mathrm{~kb}$ centered between markers D22S280 and STS marker G49339 (Fig. 3).

We further analyzed whether chromosome $22 \mathrm{q}$ allelic loss correlates with clinical features of PETs. Remarkably, there was a strong positive correlation between the presence or development of distant metastases (liver, lung) and the rate of $\mathrm{LOH}(r=0.78 ; 95 \%$ CI: $0.54-0.91 ; P<0.0001)$, whereas no association between $22 \mathrm{q}$ loss and patient sex, age, tumor type or tumor size was identified. It was also of note that ten of eleven informative tumors with distant metastases showed LOH on chromosome band 22q12.3 compared with only three of twelve tumors without distant metastases $(P=0.0057$; Table 1$)$. After a mean follow-up of
81 months, four of thirteen patients with tumors exhibiting $\mathrm{LOH}$ at $22 \mathrm{q} 12.3$ died due to diffuse liver metastases compared with none of the patients without $\mathrm{LOH}$ at this locus. Survival analysis revealed strong positive correlation ( $\log$ rank test $P=0.032$; $\mathrm{df}=1$ ) between the presence of distant metastases and premature death, whereas a correlation between the presence of $\mathrm{LOH}$ at $22 \mathrm{q} 12.3$ and premature death was not quite achieved (log rank test $P=0.073 ; \mathrm{df}=1)$.

\section{Discussion}

LOH studies are a powerful tool to assess the status of particular gene loci in the development and progression of human neoplasms (11). The goal of this study was to evaluate whether chromosome $22 \mathrm{q}$ contains a tumor suppressor gene region associated with the development or progression of PETs. Utilizing a large number of microsatellite markers we could show, for the first time, that 22 of $23(96 \%)$ reveal LOH on chromosome $22 \mathrm{q}$ with marker D22S1167 showing an LOH rate of $85 \%$ (17 of 20 informative tumors) at locus $22 \mathrm{q} 12.1$. This is in contrast to three previous reports that observed $\mathrm{LOH}$ at the long arm of chromosome 22 in only $0-38 \%$ of PETs $(12-15)$. There are several possible explanations for this discrepancy of overall $\mathrm{LOH}$ rates. First, three of the studies $(12-14)$ used at most three markers that were in the main different from ours, whereas we used 12 markers enhancing the chance for detecting LOH. The study of Rigaud et al. (15) analysed seven markers on $22 \mathrm{q}$ in 16 non-functioning PETs, including markers D22S280, D22S283 and D22S423, and found LOH rates of 35\% $42 \%$ and $35 \%$ respectively. These $\mathrm{LOH}$ rates are statistically not different from the $\mathrm{LOH}$ rates of $59 \%, 48 \%$ and $36 \%$ detected in the present study, given the small number of PETs analyzed and the relatively high number of non-informative cases in the study of Rigaud et al. (15). Second, the differences may relate to different tumor populations and to different amounts of contaminating normal DNA in the tumor samples. Third, intermediate levels of allele retention could theoretically also be due to a variable degree of intratumoral gene amplification of one chromosomal copy. Fourth, intratumoral genetic heterogeneity is a known feature of PETs $(14,16)$, that can result in complete loss of chromosomal material or varying levels of allelic retention.

The present examination of a large number of microsatellite markers encompasses more than $25 \mathrm{Mb}$ and about $82 \%$ of the coding regions of chromosome $22 \mathrm{q}$. PETs with distant metastases revealed loss of larger portions of 22q, whereas PETs without distant metastases often showed smaller regional deletions. In previous comparative genomic hybridization (CGH) and karyotyping studies of PETs, only very few genomic losses on chromosome 22q, comprising either the entire 
chromosomal arm or large portions of $22 \mathrm{q}$, were identified (17-21). This discrepancy can be explained by the limited resolution $(10-20 \mathrm{Mb})$ of the CGH and karyotyping methods so that smaller deletions $(<10 \mathrm{Mb})$ usually cannot be detected (22). However, in concordance with these CGH studies, our data show that PETs from patients with advanced metastatic disease had higher numbers of chromosomal alterations than tumors from patients with localized tumors. These data underscore the hypothesis that the progression of PETs towards an aggressive malignant phenotype goes along with an accumulation of genetic changes, as has been suggested by previous studies $(21,22)$. Furthermore, it can be speculated that genes guarding chromosomal stability by their involvement in mitotic replication and segregation of chromosomes might be important players in PET progression.

Taking advantage of information available on the precise position and size of polymorphic markers in this chromosomal area (10), it is possible to estimate the locus of interest as approximately $2.5 \mathrm{Mb}$ $(4.3 \mathrm{cM})$. The deletions in our material were large, in all but three cases extending centromerically to the tumor suppressor gene hSNF5/INI1 on 22q11.23 and telomerically to the tumor suppressor gene neurofibromatosis type 2 gene (NF2) on $22 \mathrm{q} 12.2$ in $44 \%$ and $75 \%$ of positive cases respectively. The tumor suppressor gene $h S N F 5 / I N I 1$ encodes a widely expressed component of the chromatin-remodeling SWI/SNF multiprotein complex involved in the regulation of gene expression in the cell nucleus (23). Numerous loss-of-function mutations and homozygous deletions have been identified in malignant rhabdoid tumors as well as in medulloblastomas (24). Although hSNF5/ INI1 appears to be an attractive candidate gene, no alterations could recently be identified in insulinomas (25). Somatic mutations in the tumor suppressor gene NF2, localized at 22q12.2, have been identified in neurofibromatosis type 2-related tumors, such as sporadic meningiomas and vestibular schwannomas (26). It is suggested that NF2 may act as a membrane-associated molecular switch that regulates cell-cell and cell-matrix signals transduced by cell surface receptors. Since $75 \%$ of the analyzed PETs revealed $\mathrm{LOH}$ at the NF2 locus, this gene warrants future evaluation to determine its role in the development of PETs.

We identified a second region of interest at chromosomal band 22q12.3, since one NNPC (166/98) revealed a homozygous deletion of marker D22S280 in this region that was characterized by an $\mathrm{LOH}$ rate of $59 \%$. Fine deletion mapping of tumors exhibiting $\mathrm{LOH}$ or without $\mathrm{LOH}$ at this locus revealed no additional tumors with homozygous deletions. However, tumor 166/98 showed homozygous deletion of two adjacent markers that allows estimation of the locus of interest as approximately $70 \mathrm{~kb}$. According to the map of chromosome $22 \mathrm{q}$ there are two candidate genes localized in this area, namely synapsin 3 (SYN3) and tissue inhibitor of metalloproteinase-3 (TIMP-3). SYN3 belongs to a family of neuron-specific synaptic vesicle-associated phosphoproteins that have been implicated in synaptogenesis and in the modulation of neurotransmitter release, but no association with tumor development has yet been identified (27). The second gene, TIMP-3, has been localized within an intron of the SYN3 gene. TIMP-3 is a member of the family of secreted inhibitors that blocks the activity of metalloproteinases, therefore regulating matrix composition, cell growth, invasion and migration (28). It has been shown that TIMP-3 is implicated in tumor progression, including the development of metastases (29). Furthermore, it has also been suggested that TIMP-3 might function as a tumor suppressor, since methylation-associated silencing and loss of expression was identified in kidney, brain and some lung tumors (30). Thus, TIMP-3 appears to be an attractive candidate for genetic analysis in PETs to clarify its role in the tumorigenesis of these tumors.

Although the histological characteristics of PETs are very similar, their malignant potential varies greatly. Currently, there is no histopathologic feature other than the presence of gross metastases or infiltrating overgrowth that can reliably distinguish benign from malignant PETs. High expression of chromogranin A, high Ki-67 index or abnormal DNA content have been suggested to indicate malignant tumors $(4,14)$, but per se they are no evidence of a malignant phenotype (3). Previously, LOH on chromosomes 1, 3p and 11 q13 have been also proposed as potential predictors of malignancy and prognosis in PETs $(4,6,8)$. However, these small-scale studies await confirmation in a larger population of patients with PETs. In our present study, allelic loss on chromosome $22 \mathrm{q}$ seems to be strongly correlated with the occurrence of distant metastasis $(r=0.78 ; P<0.0001)$, especially $\mathrm{LOH}$ at chromosomal band 22q12.3 $(P=0.0057)$. As expected, there was a strong positive correlation in survival analysis between presence of distant metastases and premature death (log rank test $P=0.032$; $\mathrm{df}=1)$. The correlation between the presence of $\mathrm{LOH}$ on 22 q12.3 and premature death did not quite reach significance (log rank test $P=0.073$ ). This may be due to the limited number of cases and the fact that survival estimates were censored for the group of tumors without $\mathrm{LOH}$ at $22 \mathrm{q} 12.3$, since none of the patients died in this group during follow-up. However, the data presented indicate a prognostic distinction between tumors with lymph node involvement alone and those with distant metastases. Our findings correspond well with available clinical studies of gastrinomas showing that sole lymph node involvement has a relatively good prognosis (31). Based on our data, one might hypothesize that loss of a putative tumor suppressor gene on chromosome $22 \mathrm{q} 12.3$ is more likely associated with suppression of the metastatic processes 
rather than with regulation of other aspects of cellular growth or differentiation.

In summary, the high frequency of LOH on chromosome 22q12.1 and 22q12.3 indicates two loci compatible with harboring tumor suppressor genes that may be associated with the tumorigenesis of PETs. Large-scale controlled studies are warranted to determine whether allelic loss of 22q12.3 may be a useful prognostic marker for PETs.

\section{Acknowledgements}

We thank all patients for participation in the study. This work was supported by the Deutsche Krebshilfe (Grant No 10-1674-Ba I).

\section{References}

1 Klöppel G, In’t Veld PA, Stamm B \& Heitz PU. The endocrine pancreas. In Functional Endocrine Pathology, pp 396-421. Eds K Kovacs \& SL Asa. Boston: Blackwell Scientific Publications, 1990.

2 Solcia E, Klöppel G \& Sobin L. Histological typing of endocrine tumors. In WHO Classification of Endocrine Tumors, edn 2, ch. V, pp 56-60. Berlin: Springer, 2000.

3 Pelosi G, Bresaola E, Bogina G, Pasini F, Rodella S, Castelli P et al. Endocrine tumors of the pancreas: Ki-67 immunoreactivity on paraffin sections is an independent predictor for malignancy: a comparative study with proliferating-cell nuclear antigen and progesterone receptor protein immunostaining, mitotic index, and other clinicopathologic variables. Human Pathology 1996 27 1124-1134.

4 Hessman O, Lindberg D, Einarsson A, Lillhager P, Carling T, Grimelius L et al. Genetic alterations on 3p, 11q13, and 18q in nonfamilial and MEN1-associated pancreatic endocrine tumors. Genes, Chromosomes \& Cancer 199926 258-264.

5 Caron H, van Sluis P, de Kraker J, Bokkerink J, Egeler M, Laureys G et al. Allelic loss of chromosome $1 \mathrm{p}$ as a predictor of unfavorable outcome in patients with neuroblastoma. New England Journal of Medicine $1996334225-230$.

6 Chung DC, Smith AP, Louis DN, Graeme-Cook F, Warshaw A \& Arnold A. A novel pancreatic endocrine tumor suppressor gene locus on chromosome $3 \mathrm{p}$ with clinical prognostic implications. Journal of Clinical Investigation $1997 \mathbf{1 0 0} 404-410$.

7 Bartsch DK, Hahn SA, Danichevski KD, Ramaswamy A, Bastian D, Galedhari H et al. Mutations of the DPC4/Smad4 gene in neuroendocrine pancreatic tumors. Oncogene 199918 2367-2371.

8 Ebrahimi SA, Wang EH, Wu A, Schreck RR, Passaro E Jr \& Sawicki MP. Deletion of chromosome 1 predicts prognosis in pancreatic endocrine tumors. Cancer Research $199959311-315$.

9 Langer P, Bartsch D, Gerdes B, Schwetlick I, Wild A, Brehm B et al. Renin producing neuroendocrine pancreatic carcinoma - a case report and review of the literature. Experimental and Clinical Endocrinology and Diabetes $200211043-49$.

10 Dunham I, Shimizu N, Roe BA, Chissoe S, Hunt AR, Collins JE et al. The DNA sequence of human chromosome 22. Nature $1999 \mathbf{4 0 2}$ 489-495.

11 Stanbridge EJ \& Nowell PC. Origins of human cancer revisited. Cell $199063867-874$.

12 Chung DC, Brown SB, Graeme-Cook F, Tillotson LG, Warshaw AL, Jensen RT et al. Localization of putative tumor suppressor loci by genome-wide allelotyping in human pancreatic endocrine tumors. Cancer Research 199857 3706-3711.

13 Nikiforova MN, Nikiforova YE, Biddiger P, Gnepp DR, Grosembacher LA, Wajchenberg BL et al. Frequent loss of heterozygosity at chromosome 3p14.2-3p21 in human pancreatic islet cell tumours. Clinical Endocrinology $19995127-33$.
14 Hessman O, Skogseid B, Westin G \& Akerström G. Multiple allelic deletions and intratumoral genetic heterogeneity in MEN1 pancreatic tumors. Journal of Clinical Endocrinology and Metabolism 200186 1355-1361.

15 Rigaud G, Missiaglia E, Moore PS, Zamboni G, Falconi M, Talamini $\mathrm{G}$ et al. High resolution allelotype of nonfunctional pancreatic endocrine tumors: identification of two molecular subgroups with clinical implications. Cancer Research $200161285-$ 292.

16 Perren A, Roth J, Muletta-Feurer S, Saremaslani P, Speel EJ, Heitz PU et al. Clonal analysis of sporadic pancreatic endocrine tumours. Journal of Pathology $1998 \mathbf{1 8 6} 363-371$.

17 Long PP, Hruban RH, Lo R, Yeo CJ, Morsberger LA \& Griffin CA. Chromosome analysis of nine endocrine neoplasms of the pancreas. Cancer Genetics and Cytogenetics 199477 55-59.

18 Terris B, Meddeb M, Marchio A, Danglot G, Flejou JF, Belghiti J et al. Comparative genomic hybridization analysis of sporadic neuroendocrine tumors of the digestive system. Genes, Chromosomes \& Cancer 199822 50-56.

19 Stumpf E, Aalto Y, Hoog A, Kjellman M, Otonkoski T, Knuutila S et al. Chromosomal alterations in human pancreatic endocrine tumors. Genes, Chromosomes E Cancer 200029 83-87.

20 Speel EJ, Scheidweiler AF, Zhao J, Matter C, Saremaslani P, Roth J et al. Genetic evidence for early divergence of small functioning and nonfunctioning endocrine pancreatic tumors: gain of 9Q34 is an early event in insulinomas. Cancer Research 200161 5186-5192.

21 Zhao J, Moch H, Scheidweiler AF, Baer A, Schaffer AA, Speel EJ et al. Genomic imbalances in the progression of endocrine pancreatic tumors. Genes, Chromosomes E Cancer $200132364-372$.

22 Speel EJ, Richter J, Moch H, Egenter C, Saremaslani P, Rutimann K et al. Genetic differences in endocrine pancreatic tumor subtypes detected by comparative genomic hybridization. American Journal of Pathology $19991551787-1794$.

23 Reyes JC, Muchardt C \& Yaniv M. Components of the human SWI/SNF complex are enriched in active chromatin and are associated with the nuclear matrix. Journal of Cell Biology 1997 $137263-274$.

24 Versteege I, Sevenet N, Lange J, Rousseau-Merck MF, Ambros P, Handgretinger $\mathrm{R}$ et al. Truncating mutations of hSNF5/INI1 in aggressive paediatric cancer. Nature 1998394 203-206.

25 Wild A, Langer P, Ramaswamy A, Chaloupka B \& Bartsch DK. A novel insulinoma tumor suppressor gene locus on chromosome $22 \mathrm{q}$ with potential prognostic implications. Journal of Clinical Endocrinology and Metabolism 200186 5782-5787.

26 Gutmann DH. The neurofibromatoses: when less is more. Human Molecular Genetics 200110 747-755.

27 Kao HT, Porton B, Czernik AJ, Feng J, Yiu G, Haring M et al. A third member of the synapsin gene family. PNAS $1998 \mathbf{9 5}$ 4667-4672.

28 Birkedal-Hansen H, Moore WG, Bodden MK, Windsor LJ, DeCarlo A \& Engler JA. Matrix metalloproteinases: a review. Critical Reviews in Oral Biology and Medicine $19934197-250$.

29 Ahonen M, Baker AH \& Kahari VM. Adenovirus-mediated gene delivery of tissue inhibitor of metalloproteinases-3 inhibits invasion and induces apoptosis in melanoma cells. Cancer Research $1998582310-2315$.

30 Bachman KE, Herman JG, Corn PG, Merlo A, Costello JF, Cavenee WK et al. Methylation-associated silencing of the tissue inhibitor of metalloproteinase-3 gene suggests a suppressor role in kidney, brain, and other cancers. Cancer Research 199959 798-802.

31 Weber HC, Venzon DJ, Lin JT, Fishbein VA, Orbuch M, Strader DB et al. Determinants of metastatic rate and survival in patients with Zollinger-Ellisson syndrome: a prospective long-term study. Gastroenterology $1995 \mathbf{1 0 8} 1637-1649$.

Received 20 March 2002

Accepted 25 June 2002 